\title{
A Comparative Study of Hajj Fund Management Institutions in Malaysia, Indonesia and Maldives
}

\author{
Aishath Muneeza, \\ Amira Shuhadabinti Tamby Sudeen, \\ Atiqoh Nasution, \\ Ratih Nurmalasari
}

International Centre of Education for Islamic Finance (INCEIF), Malaysia

\begin{abstract}
:
Performing hajj is one of the five pillars of Islam which may become compulsory for a Muslim who has financial ability to perform this ibadah at least once in his lifetime. To facilitate Muslims to fulfil this religious obligation, countries which have majority Muslim population like Malaysia, Indonesia and Maldives have established legal entities/institutions to manage hajj funds from hajj depositors (aspirant pilgrims) and provide services related to hajj. Although these institutions share the same objective in terms of helping Muslims to perform hajj, their operational activities are largely different. This paper aims to contribute to the understanding of hajj fund management institution in these three different jurisdictions. This understanding is important for policy makers and regulators regulating hajj fund management. It is anticipated that the outcome of this research will shed a light on hajj fund management in Asia.
\end{abstract}

Keywords: Hajj Funds Management, Maldives Hajj Corporation, Tabung Haji Malaysia, Badan Pengelola Keuangan Haji, Hajj Administration, Ministry of Religious Affairs 


\section{Introduction}

Hajj is a pilgrimage to Mecca in Saudi Arabia during the last month of Islamic calendar (Dhul-Hijjah), and it is mandatory for a Muslim who has financial ability to perform this ibadah at least once in his or her lifetime. Each year, 2-3 million people perform Hajj. In 2017, the total number of pilgrims to perform hajj was officially reported as 2,352,122 (General Authority for statistics, 2018). The actual event lasts over five days, and the pilgrims typically visit and perform a series of rituals in several sacred sits (Henderson, 2010).

For Muslims, hajj is a demonstration of the submission of Muslim to their God (Allah) and the completion of the hajj has religious and social significance to Muslims. For them, performing hajj is also a financial commitment due to the costs associated with Hajj. The costs of attending the hajj varied by country and the travel companies which operate Hajj tours. The average cost for British Muslims to perform Hajj is $£ 4,750$ per person (Cochrane, 2018), where all meals and drinks are included.

As countries with majority of Muslim population, Malaysia, Indonesia and Maldives, have a dedicated separate legal entity/institution aiming to organize hajj affairs for their Muslim citizens. As part of the function to perform the duty, the institution has to manage the hajj fund accumulation as a result of the deposit from hajj pilgrim depositors. Tabung Haji in Malaysia, Badan Pengelola Keuangan Haji in Indonesia and the Maldives Hajj Corporation Limited in Maldives are the institutions that have the responsibility to perform such function. Although their main objectives and responsibilities are similar, these institutions have different concepts and modus operandi.

Established in 1963, Tabung Haji in Malaysia is the oldest and the most renowned institution which is claimed to be successful in managing the hajj fund in an innovative way (Bianchi, 2004; Cizakca, 2011). In Maldives, the formation of the Maldives Hajj Corporation Limited in 2013 by the Maldives government has gained trust from Maldivian Muslims in providing service for hajj affair. Indonesia, a close neighbour of Malaysia with the largest Muslim population in the world, has a monopoly of hajj services since the 1970s (Bianchi, 2004). The Ministry of Religious Affairs collect down-payment for hajj pilgrimage cost or Biaya Penyelenggaraan Ibadah Haji (BPIH) from hajj pilgrim depositors. Over the years, there are frequent allegations of fraud and corruption surrounding hajj fund management in Indonesia (Onishi, 2010), until the establishment of Law No. 34/2014 which is intended to reform the hajj fund management to be more efficient, transparent and accountable so that it can enhance the value for the operation of hajj affair. Although this law was issued since 2014, the hajj fund management agency (BPKH) as the official independent agency mandated by this law, has just been formed in 2017 and began its operation in 2018.

The purpose of the study is to improve our understanding of the importance of the hajj management and illuminate the challenges of managing hajj fund in different jurisdictions. This research is divided into four parts. Followed by this introduction, the second part of this research explains the research methodology and the third part

International Journal of Management and Applied Research, 2018, Vol. 5, No. 3 
of the research presents hajj management in Malaysia, Indonesia and Maldives. Following to that, a discussion of hajj fund management in these countries is presented. The final part of this paper is the conclusion where the main findings of this research are summarized.

\section{Research Methodology}

A desk research based on scholarly works and legal documents was conducted to provide an insight regarding hajj management in Malaysia, Indonesia and Maldives. Sources such as laws, orders, decisions, or regulations issued by a governmental entity are used to form the basis of legal environment in different countries. Other published sources such as books, academic journals, newspapers, and magazines are also reviewed as part of this research. However, there is limited information available in English since English is not the primary language in these countries. Moreover, Tabung Haji and Ministry of Religious Affairs do not have a formal archive, making it difficult to conduct research about their establishment and evolution to the present time being (Cizakca, 2011)

\section{Hajj Management in Malaysia, Indonesia and Maldives}

Handling the influx of millions of pilgrims is a massive logistical challenge for Saudi Arabia (Cochrane, 2018). Supervised by the Supreme Hajj Committee, the Ministry of Hajj and Umrah in Saudi Arabia is responsible for hajj management (Henderson, 2010). The Hajj authorities have invested tremendous efforts to ensure health and safety of pilgrims, especially in the areas of transport planning, crowd management, air quality monitoring, and healthcare services (Cochrane, 2018). Saudi Arabia sets Hajj quotas, which allows $0.1 \%$ of the Muslim population of each country to perform Hajj each year. In 2017, there were around 1.8 million pilgrims came from outside Saudi Arabia to attend Hajj (General Authority for statistics, 2018). To perform Hajj, applicants must consult a licensed agency in their home country, and complete application formed authorised by the agency (Henderson, 2010). The Hajj visa holders must also carry vaccination certificates with them for inspection, and they are not allowed to bring foods into the Kingdom of Saudi Arab and remain in the country after the completion of Hajj (The Embassy of The Kingdom of Saudi Arabia, n.d.).

Despite technological advances in air travel and communication, the costs of travel to Mecca and its associated costs (lodging, transport, and meal) continue to rise. A Hajj package for British Muslims, for instance, has increased nearly $400 \%$ within a decade (Pigott, 2010). Contemporary pilgrimage management has spread throughout the Islamic countries. Malaysia is one of the first countries to create a well-funded hajj bureaucracy where the country set the international standard in pilgrim education and subsidized air travel in the 1960s (Bianchi, 2004; Cizakca, 2011). In 1970s, Indonesia established a haji regime that centralised resources and authority in the Ministry of Religious Affairs (Bianchi, 2004). Over the past few decades, the Indonesian government introduced Law No. 17/1999, 23/2008, 34/2014 to regulate hajj administration. Maldives, on the other hand, has not regulated any activities related to hajj until 2013 when the government of Maldives formed Maldives Hajj Corporation Limited.

International Journal of Management and Applied Research, 2018, Vol. 5, No. 3 
This paper focuses on the development of hajj management in these three countries. More specifically, these three countries were selected due to the different stages each country represent in developing hajj management and fund trust. While Malaysia represents an innovator and Indonesia as an early adaptor, Maldives represents the majority (Rogers, 1995). Figure 1 presents the adoption curve of hajj fund management among these countries.

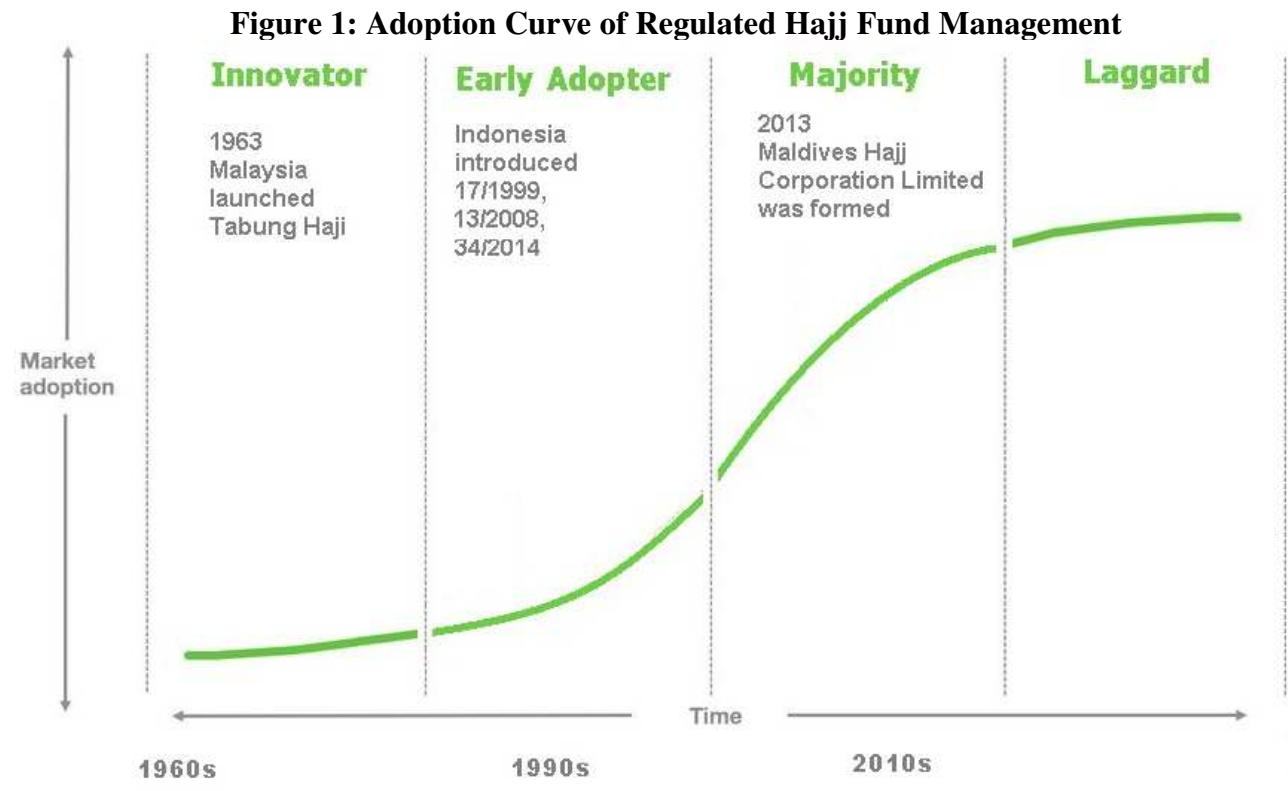

Adapted from: Rogers (1995)

\subsection{Malaysia}

Launched in 1963, Tabung Haji began as a pilgrim fund board, and the institution has developed the most "modern and profitable pilgrimage administration in the world" (Bianchi, 2004: 117). The fundamental concept behind the institution is to enable Muslims to save for pilgrimage without fear of the money being tainted by riba. Under Islamic law, Muslims are forbidden from involving in economic activities that generate financial interest ( $r i b a$ ). Since putting personal savings in commercial banks is considered as interest-bearing deposits which contradicts Islamic law, traditional Malays hid their money "in bamboos or even in mattress" (Cizakca, 2011: 209) or resorted to crude means of saving in the form of land, jewellery or livestock (Hamidon, 2014). The establishment of Lembaga Urusan Tabung Haji has encouraged the Malays to save their money in a more efficient way. Additionally, the institution aims to help pilgrims in dealing issues related to Hajj visa, passport, transportation, accommodation in Saudi Arabia (Tabung Haji, n.d.).

The literal translation of Tabung Haji would be "pilgrimage piggy bank" (Bianchi, 2004: 113) and its business model is different from the corporate world and traditional banking. Due to prohibition of interest (riba), Tabung Haji does not lend to people as loans. Instead, they collect savings from the depositors and invest strategically. The 
financial functions of Tabung Haji are categorised into two major activities. The first concerns with financial management including savings and withdrawal of funds by the depositors, and the second is related to the investment carried out upon their savings. In short, Tabung Haji facilitates savings for the pilgrimage to Mecca through Shariah-compliant investment.

\subsubsection{Fund Management}

From the 1980s, the investment portfolio of Tabung Haji diversified, with an involvement in agriculture, construction, and manufacturing (Gomez et al., 2017). The diversified investments in various sectors have enabled Tabung Haji to cover the rising costs of hajj operations as well as continue to subsidise the cost of Hajj for Malaysian pilgrims every year. In the 2010s, Tabung Haji has established 17 subsidiaries with direct investment of the deposit, and these subsidiaries span across different sectors, including finance, plantation, construction, telecommunications, utilities, property development, oil and gas, and others (Tabung Haji, 2016). According to Gomez et al. (2017), the aggressive strategy of entering various sectors is due to the growing popularity of Islamic finance products and services. This view is supported by Handley (1997) who reported the growth of Islamic banking in Malaysia during the late 1990s. The modus operandi of Tabung Haji is depicted in Figure 2.

Figure 2: Modus Operandi of Tabung Haji

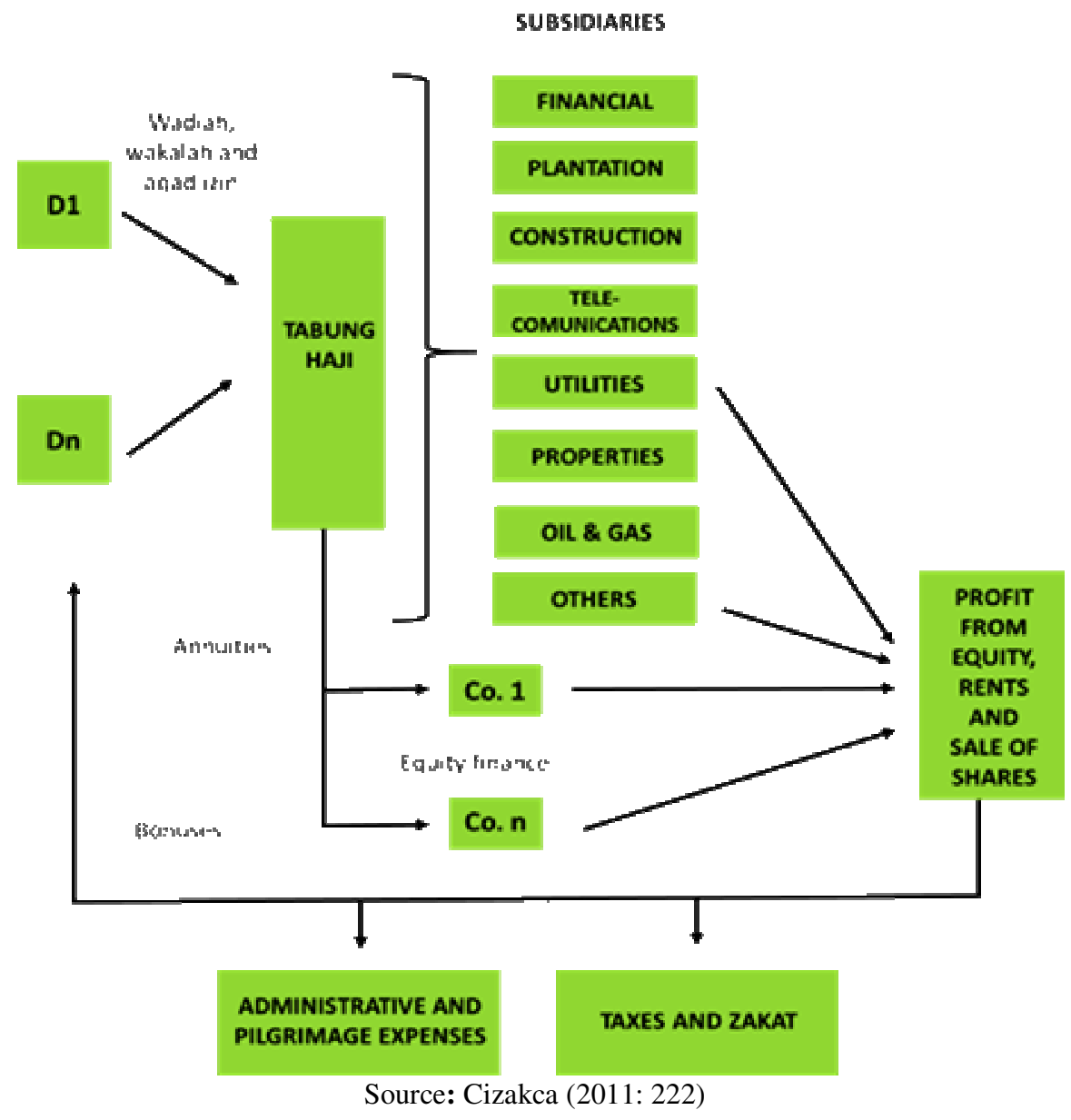

International Journal of Management and Applied Research, 2018, Vol. 5, No. 3 
The D1 and Dn denoted deposits made by prospective pilgrims. They are using wadiah yad dhamanah, interest free deposits for safekeeping. Depositors authorize Tabung Haji with a wakalah document to invest their deposits. The depositors, a Malaysian Muslim, enter into a contract by filling in the Depositors Personal and Nomination Form and which includes the statement of aqad izin. The aqad izin statement means that the depositors agree to save in Tabung Haji and give consent for it to manage their savings for investment purposes (Cizakca, 2011). Based on the consent given by depositors, Tabung Haji mobilises small savings and invest them in major industrial, agricultural, commercial, and real estate projects in accordance with Shariah principles (Cizakca, 2011; Gomez et al., 2017). Additionally, Tabung Haji also launched Restricted Investment Account "RIA" which aims to fund Muslim entrepreneurs and small businesses.

Tabung Haji grants working capital financing that mainly involves six financial instruments: profit-loss sharing (Musharaka), profit-sharing (Mudarabah), leasing (Ijarah), cost-plus financing (Murabaha), interest-free loan (Qardhul Hasan), deferred payment sale (Bai Bithaman Ajil).

Administrative and pilgrimage expenses include all the expenses of sending pilgrims to Mecca as well as organising training and publishing materials related to Hajj preparation (Bianchi, 2004; Cizakca, 2011). Although expenses for each pilgrim have increased each year, Tabung Haji is maintaining the payment for each Haj pilgrim at RM9,980 and subsidise the remaining cost to perform Hajj, which is around RM12,000 (Tabung Haji, 2016). In 2018, the total cost for Malaysian Muslim to perform Hajj is RM22,450 (Tabung Haji, 2018). For a Malaysian pilgrim who is performing his/her Hajj for the first time, the cost is capped at RM9,980 per person since 2013, where Tabung Haji subsidise the remaining costs (Tabung Haji, 2018). In addition to pilgrimage expenses, Tabung Haji also pays zakat (religious tithe) on behalf of its depositors.

After deduction of taxes, administrative and pilgrimage expenses, the profit derived from these investments will distributed among the depositors in the form of a bonus yearly basis. Average annual dividends during the $1990 \mathrm{~s}$ stood at 8.5 percent (Handley, 1997); more recently however, total bonus rate for 2017 stood at 6.25 per cent (Tabung Haji, 2017).

The success of Tabung Haji can be attributed to the government policies -- especially New Economic Policy of the 1970s and 1980s -- that favored enormously the fund (Bianchi, 2004; Cizakca, 2011; Handley, 1997). The NEP required both foreign and domestic investors to divest 30 percent of their businesses to native Malay institutions or individuals. At that time, Tabung Haji was highly respected and popular among foreign investors seeking a Malay partner (Cizakca, 2011; Handley, 1997).

\subsubsection{Challenges}

Tabung Haji has faced two main challenges over the years. The first challenge came from conservative religious leaders during late 1970s and early 1980s, who argued that air travel gives less time for group discussion related to spiritual preparation for

International Journal of Management and Applied Research, 2018, Vol. 5, No. 3 
Hajj, compared to traditional sea travel (Bianchi, 2004). Tabung Haji responded to the criticism by organising spiritual courses and sessions detailing the trip to Mecca (Bianchi, 2004), which continue to exist to date (Tabung Haji, n.d.). The second challenge is to restore stakeholder trust after a number of financial scandals. In the early 2000s, Tabung Haji was accused of financial mismanagement and poor investment (Bianchi, 2004; Lopez, 2004). During the 2000s, Tabung Haji was burdened with poor investment made in the 1990s which include overpriced property acquisitions and "sour loans" to Malaysian businesses (Lopez, 2004). In response to claims that Tabung Haji's risky approach to investments, chief executive officer at that time -- Ismee Ismail -- refuted that claim and insisted that all proposals go through a complex investment process which involves independent committees and argued that there is no need to change the process (The Star, 2010).

In 2015, local media have raised concerns that the fund was being misused for political purposes, when Tabung Haji purchased a small plot of land from 1 Malaysia Development Bhd's (1MDB) for an inflated price to cover a pressing debt payment (Malay Mail, 2015; Sarawak Report, 2016). It also became known that the CEO of Tabung Haji, Ismee Ismail, was also a director in 1MDB (Malay Mail, 2015). In 2016, Sarawak Report revealed Tabung Haji violated its own rules, including Section 21 of Lembaga Tabung Haji Act of 1995 which says that its reserve must match its liabilities and also Section 22 of the Act, which stipulates that it must not issue bonuses that exceed its profit. Nearly 4,000 depositors closed their accounts in 2016 after a loss of confidence in Tabung Haji (New Strait Times, 2018).

To sum up, Tabung Haji has a holistic ambition to encompass all economic activities related to Islam, ranging from personal finance to religious tax, as well as from pilgrimage to investment. Notwithstanding its recent reputation, it is important to acknowledge how well it serves and prepares the pilgrims throughout the years. With a modest scale of only RM46,610 deposited by 1,281 depositors in its first year of operation, Tabung Haji has now more than 9 million depositors and RM73 billion funds in 2017 (Tabung Haji, n.d.). Table 1 summarises the number of depositors and deposits over the years.

Table 1: Summary of Lembaga Tabung Haji's Performance

\begin{tabular}{rrr}
\hline Year & Total number of depositors (people) & Total of deposits $(\mathbf{R M})$ \\
\hline 1963 & 1,281 & 46,610 \\
1964 & 6,566 & 816,146 \\
1990 & 1.7 million & 1 billion \\
2008 & 4.7 million & 17 billion \\
2009 & 5 million & 23 billion \\
2012 & 8.2 million & 38 billion \\
2013 & 8.3 million & 45 billion \\
2014 & 8.6 million & 54 billion \\
2015 & 8.8 million & 62 billion \\
2016 & 9.1 million & 67 billion \\
2017 & 9.3 million & 70 billion \\
\hline
\end{tabular}

Source: Cizakca (2011: 216-217); Handley (1997); Tabung Haji (2017)

International Journal of Management and Applied Research, 2018, Vol. 5, No. 3 


\subsection{Indonesia}

For decades, the Indonesian government has a monopoly on the organisation of Hajj to Mecca based on Law 17/1999 (Bianchi, 2004). Indonesian Muslims who plan to perform hajj are required to make a down-payment of 25 million rupiah $(\$ 2,200)$, and they are typically put on a waiting list of twelve years before performing pilgrimage (Bland, 2014). The Ministry of Religious Affairs developed an innovative application, SISKOHAT, which helps Indonesians to monitor their status on the waiting list for the pilgrimage (OECD, 2016).

\subsubsection{Fund Management}

Since 2004, the hajj fund is still conservatively managed by putting the fund in banking products which are considered as short term investment and liquidity instruments and sukuk with long term maturity tenor (Bland, 2014). There are frequent allegations of corruption (Onishi, 2010) and poor management (Bianchi, 2004).

The issuance of Law No. 34/2014 becomes a breakthrough in hajj fund management in Indonesia. This law obliges the formation of hajj fund management agency or Badan Pengelola Keuangan Haji (BPKH) as an independent public legal entity to manage hajj fund and it is accountable to the president through the Minister of Religious Affairs. Although the law has been issued since 2014, the members of BPKH were inaugurated in 2017 by the president and officially began operation in 2018.

In terms of contract ('aqd), prior to the establishment of Law No. 34/2014, the fund was agreed for safekeeping purpose only to perform hajj and therefore, it could not be used or managed for other purposes. Under this contract, the hajj pilgrim depositors signed wakalah contract agreement when they deposited their down-payment and as muwakkil, they entrusted the Ministry of Religious Affairs as representative (wakil), to receive and manage their down-payments in accordance with the regulation (Jumali, 2018).

Returns from the deposits and investments will be used in three ways: firstly, to subsidise the cost of attending annual pilgrimage to Mecca; secondly, to cover the operational expenses, and lastly, to return to the prospective pilgrims' accounts (Winosa, 2017). Before the issuance of Law No. 34/2014, there was no specific and predetermined strategy in managing the hajj fund. The accumulated fund from the hajj pilgrim depositors was pooled in the bank accounts under the administration of the Ministry of Religious Affairs. In terms of banking selection, there was no strict requirement for the hajj fund to be placed in Islamic banks (Law No. 13/2008) and thus it is likely that some portion of the hajj fund, if not all, was saved in conventional banks which were not Shariah-compliant. Mandatory requirement for using Sharia banks for placing the hajj fund was issued in 2013 through the Decree of Minister of Religious Affairs.

According to Law No. 34/2014, BPKH is now able to diversify the investment portfolio into more productive activities which likely generate more benefit to the

International Journal of Management and Applied Research, 2018, Vol. 5, No. 3 
depositors as the primary beneficiaries and improve welfare of the Muslim community. However, BPKH needs to consider factors such as the selection of lowrisk instruments, the added value creation for hajj pilgrim depositors and the operation must comply with Sharia principles.

In 2017, BPKH manages IDR106 trillion hajj fund (Abimanyu, 2017). Profit or financial return generated from the hajj fund investment activities will be credited into the hajj pilgrim depositors' virtual accounts by BPKH periodically and the amount will be determined by BPKH (Law No. 34/2014). However, due to limited data, the amount of depositors and the return on investments given to the depositors are unknown.

In addition to mitigate the fraudulent risk over the hajj fund management at BPKH, there is specific clause which states that the implementation body (Badan Pelaksana) and the supervisory body (Dewan Pengawas) of BPKH are jointly and severally liable for any loss due to the negligence in managing the hajj fund (Law No. 34/2014).

\subsubsection{Challenges}

One major challenge to BPKH is to bridge the gap between pilgrimage fees (BPIH) that Indonesians need to pay and the actual cost of performing Hajj. The actual cost of performing pilgrimage is around IDR60-70 million per person, which is 50\% more than the pilgrimage fees (BPIH) required by law (Muhyiddin, 2018). This naturally leads to second challenge, that is, to increase hajj fund investment yield through lowrisk and high return investment projects (Abimanyu, 2017).

\subsection{Maldives}

Prior to the formation of Maldives Hajj Corporation Ltd (MHCL) hajj fund management was not regulated in Maldives. The executive body in charge of religious affairs gives authority to certain private hajj tour operators. However, private hajj tour operators have either provided poor services to the pilgrims or fraudulently collected funds from pilgrims. Numerous incidents have happened in the past, namely, Maleesha Hajj Group scandal (Minivan News, 2012) and Al-Fath'h Hajj and Umra Group (Vnews, 2014). Due to these incidents, the then Deputy Minister of Ministry of Islamic Affairs and the first chairperson of MHCL made a public statement saying that the government should stop giving permission for the private hajj groups to take people to hajj (Vnews, 2014).

\subsubsection{Fund Management}

$50 \%$ of the hajj quota received to the country is managed by MHCL and the rest of $50 \%$ of hajj quota is given to private hajj providers to manage. The risk of doing this was evident due to Al-Fath'h Hajj and Umra Group scandal. To protect public interest and prevent misappropriation of funds, MHCL was formed (Vnews, 2014).

MHCL is a state-owned enterprise formed under a presidential decree in November 07, 2013 (Sun, 2013). His Excellency President Dr. Mohamed Waheed Hassan Manik ratified the declaration 05/2013 and formed Maldives Hajj Corporation Limited, in accordance with section 95 of the companies Act 96/10. The mission of MHCL is to safeguard the finances of Maldivians who plan on performing Hajj and Umrah and the

International Journal of Management and Applied Research, 2018, Vol. 5, No. 3 
vision is to provide affordable means of performing Hajj and Umrah for Maldivians and to improve hajj administration.

There are two types of packages available for potential pilgrims intend to become a member of MHCL: lump sum package and saving package. To be eligible for lump sum package, he or she must register and at least $75 \%$ of the hajj price (MVR 69,965) must be paid and the candidate will be given hajj quota by reserving a slot for a specific year which will be notified. MHCL will take people to hajj according to order of their registration.

For the saving package, the minimum amount to be paid to be registered is MVR 500 and the person has the flexibility to pay the balance until the full amount of hajj price is reached. However, the hajj quota will only be allocated once the balance reaches $75 \%$ of the hajj price. The advantage of registering for this package is that the money received under this category will be invested in a Shariah compliant investment and the received profit will be distributed among the account holders. This, in turn, reduces the waiting duration to perform hajj. Profit from the investment will be distributed in 95:5 ratio between MHCL and the saving package holders. MHCL also introduced an employee hajj scheme to encourage participation in hajj saving scheme by automatically deducting from salary every month.

An online portal called "Faheli" is introduced in 2017 to interact with members of MHCL. The services that could be obtained this online portal include payment of hajj and umrah price without physically coming to the corporation or via financial institutions by merely using mobile phones (Miadhu, 2017).

\subsubsection{Challenges}

On $20^{\text {th }}$ January 2015, MVR 110 million have been deposited in MHCL (Sun, 2015). In 2018, it was reported by Public Service Media that MHCL has invested USD 1.9 million in Housing Development Finance Corporation (HDFC) for a 5 years term. It is reported that MHCL has been investing in HDFC since 2015, aimed to decrease the amount paid on Hajj trips by individuals through such investments (Public Service Media, 2018). However, the return from this investment is not disclosed. In the Annual Report (2014, p.85) of State Trading Organization Plc (STO) it has made reference to a corporate guarantee made to MHCL for the facilities of MVR 50 million obtained by Fuel Supplies Maldives Private Limited (FSM) proving that MHCL has made some investments in FSM. Again, the return on investment is not disclosed. However, in the Annual Report (2016, p. 45) of STO it is stated that MHCL has invested MVR 40,019,035 for a profit sharing ratio of 60:40. Due to lack of data, it is impossible to determine the impact of hajj fund investments at MHCL.

\section{Discussion}

In this paper we have described the historical and financial perspectives of hajj fund management in Malaysia, Indonesia, and Maldives. This comparative study explores an issue not previously explored in detail in the academic literature. We have identified important similarities and differences between the three countries. In terms of legal status, Tabung Haji and BPKH are the institutions that are regulated by the

International Journal of Management and Applied Research, 2018, Vol. 5, No. 3 
law passed by Parliament, while MHCL is established under Presidential Decree under Companies Act of Maldives. Both Tabung Haji and MHCL are state-owned companies, whilst BPKH is a public legal entity.

We have also demonstrated that there are important differences between Malaysia, Indonesia, and Maldives in terms of investment portfolio and hajj administration. While Tabung Haji in Malaysia has a diverse investment portfolio, MHCL in Maldives and BPKH in Indonesia have a comparatively limited investment portfolio. Table 2 illustrates types of investment made by hajj fund management institutions in these countries. For deposit contract, Tabung Haji applies wadiah yad dhamanah contract and BPKH uses Wakalah contract. The contract used by MHCL is unknown. As Bianchi (2004) noted, Indonesians have demonstrated less imagination than Malaysians in financing hajj. As of 2017, Indonesian hajj funds reached IDR106 trillion, whereas Malaysian hajj funds stood at IDR144 trillion (Abimanyu, 2017).

Table 2: Types of Investment Made by Hajj Fund Management Institutions in Malaysia, Indonesia and Maldives

\begin{tabular}{lcccc}
\hline & Islamic Banking Product & Sukuk & Equity & Small Business \\
\hline Malaysia & $\sqrt{ }$ & $\sqrt{ }$ & $\sqrt{ }$ & $\sqrt{ }$ \\
Indonesia & $\sqrt{ }$ & $\sqrt{ }$ & $\mathrm{x}$ & $\mathrm{x}$ \\
Maldives & $\sqrt{ }$ & $\sqrt{ }$ & $\mathrm{x}$ & $\mathrm{x}$ \\
\hline
\end{tabular}

Perhaps the greatest challenge for hajj fund management is accountability. Misappropriation of funds and financial scandals are not uncommon in these three countries, especially when comes to managing hajj fund. Despite Tabung Haji has the first mover advantage in Hajj management and pilgrimage fund management, its recent reputation has suffered from a series of financial scandals. Its neighbour, Indonesia, is equally recovering from scandals and corruption. Maldives, on the other hand, is still in its early days and thus it is difficult to measure its financial performances.

\section{Conclusion}

To sum up, it can be said that hajj fund management institutions play significant role for safekeeping and managing the hajj fund. Beyond these functions, in the case of Tabung Haji in Malaysia, it is proven for decades that the institution enables Malaysian Muslims to perform hajj at affordable price since the institution subsidise the pilgrims partially. By the investment mechanism it executes, the institution also indirectly provides opportunity for the hajj depositors to participate in the economic development of the country and fuel economic growth in Malaysia.

In terms of investment portfolio, Tabung Haji has a more sophisticated investment portfolio, varying from banking product, sukuk, equity, and small businesses. In Indonesia, hajj fund is placed in sukuk and BPKH aims to diversify its investment portfolio. In Maldives, the exact revenues and investment made by MHCL are

International Journal of Management and Applied Research, 2018, Vol. 5, No. 3 
unknown, but it is evident that MHCL makes investments in the businesses of state owned enterprises. Indonesia and Maldives can learn from the successful journey of Tabung Haji in Malaysia to improve their hajj fund management to have greater financial returns and at the same time, facilitate economic development and improve social welfare at national level.

Transparent disclosure to all stakeholders is important, especially for the depositors. Depositors want to know more than the mission-vision statements of an organisation. They want real statistics, and most importantly, how their deposits are invested. The website and the publications of Tabung Haji are relatively comprehensive compared to other two entities in Indonesia and Maldives. This may be due to the long history of Tabung Haji. Though institutions found in Indonesia and Maldives are not public listed companies, it is recommended to follow the same standard of corporate governance followed by a public listed company in these jurisdictions and Shariah governance followed by these companies shall be benchmarked as same level as a an Islamic bank in these jurisdiction follows.

Another area of improvement that can be considered is adopting FinTech in these operations to provide easy access to customers. Devising a mobile application or paying of deposit via mobile money or a similar platform will make the process easy from the customer's perspective especially when targeted for younger generations. MHCL of Maldives and SISKOHAT in Indonesia are exemplars in this regard. However, it shall not be forgotten that older generations should also be catered using procedures which are convenient for them.

\section{References}

1. Abimanyu, A. (2017), "Indonesia Hajj Fund Enhancing Prosperity", In: $2^{\text {nd }}$ Annual Islamic Finance Conference, Ministry of Finance Indonesia, available from:

http://www.fiskal.kemenkeu.go.id/aifc2017/index.php?r=seminarFiles/viewFile\&i $\underline{\mathrm{d}=38}$ [accessed on 2 Sept 2018].

2. Bianchi, R. (2004), Guests of God: Pilgrimage and Politics in the Islamic World, New York: Oxford University Press. https://doi.org/10.1093/0195171071.003.0007

3. Bland, B. (2014), "Indonesia taps $\$ 5.4$ bn Hajj fund for financial salvation", Financial Times, available from: https://www.ft.com/content/fe4fbfe4-956a-11e38371-00144feab7de [accessed on 2 Sept 2018].

4. Cizakca, M. (2011), Islamic Capitalism and Finance: Origins, Evolution and the Future, UK: Edward Elgar Publishing.

5. Cochrane, P. (2018), "The Economics of Hajj”, ACCA Global, available from: https://www.accaglobal.com/gb/en/member/member/accountingbusiness/2018/07/insights/economics-hajj.html [accessed on 1 Sept 2018].

International Journal of Management and Applied Research, 2018, Vol. 5, No. 3 
6. General Authority for Statistics, Kingdom of Saudi Arabia (2017), Haj Statistics, available from: https://www.stats.gov.sa/en/28 [accessed on 1 Sept 2018].

7. Gomez, E. T.; Padmanabhan, T.; Kamaruddin, N.; Bhalla, S. and Fisal, F. (2017), Minister of Finance Incorporated: Ownership and Control of Corporate Malaysia, Singapore: Springer.

8. Hamidon, S. (2014), The Development of Malay Entrepreneurs in Malaysia, Kuala Lumpur: ITBM.

9. Handley, P. (1997), "Malaysia's Pilgrims Fund looks to the future", Institutional Investor-International Edition, Vol. 22, No. 10, p. 28F.

10. Henderson, J. C. (2010), "Religious Tourism and Its Management: The Hajj in Saudi Arabia", International Journal of Tourism Research, Vol. 13, No. 6, pp. 541-552.

11. https://doi.org/10.1002/jtr.825

12. Jumali, E. (2018), "Management if Hajj Funds in Indonesia", Journal of Legal, Ethical and Regulatory Issues, Vol. 21, No. 3, pp. 1-9.

13. Lopez, L. (2004), "Malaysian Fund Undergoes Scrutiny", The Wall Street Journal, available from: https://www.wsj.com/articles/SB110184230617387008 [accessed on 1 Sept 2018].

14. Law of the Republic Indonesia Number 17 of 1999, Management of Hajj Worship, available from: https://kemenag.go.id/file/dokumen/uu/UU 1999 17.pdf [accessed on 1 Sept 2018].

15. Law of the Republic Indonesia Number 13 of 2008, Management of Hajj Worship, available from: https://kemenag.go.id/file/dokumen/UU1308.pdf [accessed on 1 Sept 2018].

16. Law of the Republic Indonesia Number 34 of 2014, Haji Financial Management, available from: https://www.kemhan.go.id/ppid/wpcontent/uploads/sites/2/2016/11/UU-34-Tahun-2014.pdf [accessed on 1 Sept 2018].

17. Malay Mail (2015), “Tabung Haji chief also 1MDB director, Umno man points out", Malay Mail, available from: https://www.malaymail.com/s/892881/tabunghaji-chief-also-1mdb-director-umno-man-points-out [accessed 26 Aug 2018].

18. Miadhu (2017), "Maldives Hajj Corporation launches an online portal", Miadhu, available at: http://www.miadhu.mv/article/en/6958 [accessed 26 September 2017].

19. Minivan News (2012), "Allegedly fraudulent head of Maleesha Hajj Group in Malaysia, reveal police", Minivan News, available at:

International Journal of Management and Applied Research, 2018, Vol. 5, No. 3 
https://minivannewsarchive.com/politics/allegedly-fraudulent-head-of-maleeshahajj-group-in-malaysia-reveal-police-46857 [accessed 2 September 2018].

20. Muhyiddin (2018), "Kekurangan Dana Haji, Ini Tanggapan BPKH”, Republika, available from: https://www.republika.co.id/berita/jurnal-haji/berita-jurnalhaji/18/03/14/p5kwzx396-kekurangan-dana-haji-ini-tanggapan-bpkh [accessed on 2 Sept 2018].

21. New Straits Times (2018), “3,105 Tabung Haji depositors who lost their spot can re-register as fresh applicants", New Straits Times, available from: https://www.nst.com.my/news/nation/2018/04/352366/3105-tabung-hajidepositors-who-lost-their-spot-can-re-register-fresh [accessed on 2 Sept 2018].

22. OECD (2016), OECD Public Governance Reviews Open Government in Indonesia, Paris: OECD Publishing.

23. Onishi, N. (2010), "In Indonesia, Many Eyes Follow Money for Hajj”, New York Times, available from: https://www.nytimes.com/2010/08/06/world/asia/06haji.html [accessed on 2 Sept 2018].

24. Pigott, R. (2010), “Are British Muslims being priced out of pilgrimages?”, $B B C$, available from: https://www.bbc.co.uk/news/uk-11749511 [accessed on 1 Sept 2018].

25. Public Service Media (2018), "Hajj Corporation to invest USD 1.9 million in HDFC", Public Service Media, available at: https://psmnews.mv/en/34978 [accessed 2 September 2018].

26. Rogers, E (1995), Diffusion of Innovations, New York: Free Press.

27. Sarawak Report (2016), Tabung Haji Insolvent - Zeti Warns PM That Fund's Mismanagement Threatens A Billion Ringgit Bail Out EXCLUSIVE!, available from: http://www.sarawakreport.org/2016/01/tabung-haji-is-insolvent-zeti-warnspm-the-funds-mismanagement-threatens-a-billion-ringgit-bail-out-exclusive/ (accessed 26 August 2018).

28. Sun (2013), "Government to establish Maldives Hajj Corporation”, Sun, available at: https://en.sun.mv/12538 [accessed 26 September 2017].

29. Sun (2015), "Minister Shaheem: Hajj Pilgrimage fee will be reduced to a level of satisfaction in future", Sun, available at: https://english.sun.mv/27221 [accessed 26 September 2017].

30. State Trading Organization (2014), Annual Report, Maldives: State Trading Organization, available at: https://sto.mv/Uploads/Report/2014.pdf [accessed 26 September 2017].

International Journal of Management and Applied Research, 2018, Vol. 5, No. 3 
31. State Trading Organization (2016), Annual Report, State Trading Organization available at:

https://sto.mv/Uploads/Report/Annual\%20Report\%202016.pdf [accessed 26 September 2017].

32. Tabung Haji (2016), 2016 Tabung Haji Annual Report, available from:

https://cms-

th.s3.amazonaws.com/Lembaga+Tabung+Haji+Annual+Report+2016.pdf

[accessed on 26 Aug 2018].

33. Tabung Haji (2017), Savings: Data \& Statistics, available from:

https://www.tabunghaji.gov.my/index.php/en/savings/general-info/data-statistic

[accessed on 26 Aug 2018].

34. Tabung Haji (2018), Hajj: Data \& Statistics, available from:

https://www.tabunghaji.gov.my/en/hajj/general-info/hajj-data-statistic [accessed on 26 Aug 2018[.

35. Tabung Haji (n.d.), About Us, available from:

https://www.tabunghaji.gov.my/index.php/en/corporate/corporate-

information/about-us [accessed on 26 Aug 2018].

36. The Embassy of The Kingdom of Saudi Arabia (n.d.), Hajj Requirement, available from: https://www.saudiembassy.net/hajj-requirements [accessed 2 September 2018].

37. The Star (2010), "Tabung Haji: No plan to change investment process", The star, available from: https://www.thestar.com.my/business/business-

news/2010/03/30/tabung-haji-no-plan-to-change-investmentprocess/\#lqo5trWsRuPdPa8M.99 [accessed on 26 Aug 2018].

38. Winosa, Y. (2017), “Independent agency to manage Indonesia's $\$ 6.7$ bln hajj fund to start in Q4", Global Islamic Economic Gateway, available from:

https://www.salaamgateway.com/en/story/independent_agency_to_manage_indon esias_6.7_bln_hajj_fund_to_start_in_q4-SALAAM26022017080529 [accessed 2 September 2018].

39. Vnews (2014), "This is the time to halt activities of private Hajj Groups", vnews, available at: http://vnews.mv/25116 [accessed 2 September 2018].

International Journal of Management and Applied Research, 2018, Vol. 5, No. 3 